\title{
Current State of Issues and Perspective of Judicial and Judicial- Expert Activity Improvement in Ukraine
}

\author{
Kotlyarenko Lidiya \\ Doctor of Biological Sciences, Professor, \\ Professor of Department of theory, methodology and organisation of physical \\ training and sports of the National University of Defence of Ukraine
}

ORCID ID 0000-0001-5237-8564 lida_oleg@ukr.net

\section{Pavlovska Nataliia}

PhD of Juridical Sciences, Associate Professor, Associate Professor of Theory and History of Law, Kyiv National Economic University, Kiev, Ukraine

ORCID ID 0000-0003-3311-0364 wwwpav@gmail.com

\section{Komarynska Yuliia}

PhD of Juridical Sciences, Associate Professor, Professor of Department of Criminology and Forensic Medicine of the National Academy of Internal

Affairs, Kiev, Ukraine

ORCID ID 0000-0002-1747-1816 ubk2006@ukr.net

\section{Nesen Olha}

Professor of the Department of Criminalistics and Forensic Medicine National Academy of Internal Affairs, Kyiv, Ukraine Candidate of Medical Sciences, Associate Professor ORCID ID 0000-0001-9340-815X katynesen@gmail.com

\section{Kotliarenko Oleksandr}

PhD in Law, Colonel Chief, Military Law Research Division, Center for Military and Strategic Studies, Ivan Chernyakhovskyi National Defense

University of Ukraine, Kyiv, Ukraine

ORCID ID 0000-0001-8776-2515 lida_oleg@ukr.net 


\begin{abstract}
Modern globalization and integration of international norms into the national legislation offers new challenges and priorities for the transposition of international standards into forensic activities of Ukraine.

The study of foreign practice of regulating forensic activities provides new opportunities to improve the quality and professional competence of forensic examinations conducted by respective institutions. Successful accession to the European community is dependent on internal democratic development, achieving new quality of society, and irreversible democratic transformations in all spheres of social life [1].

Keywords: Criminal Procedure Code of Ukraine an investigator, expert, implementation, international standards, examination, procedures, Civil Procedural Code of Ukraine.
\end{abstract}

Introduction. The concept of 'inner conviction' is used in many legal acts and scientific literature.

Thus the Civil Procedural Code of Ukraine enshrines the rule that the question of sufficiency of the evidence to establish the circumstances relevant to the case, the court decides in accordance with its inner conviction. (Article 80).

The court also evaluates evidence based on its inner conviction proceeding from a comprehensive, complete, objective and direct study of the evidence available in the case (Article 89) [2].

According to Article 94 Criminal Procedure Code of Ukraine an investigator, prosecutor, investigating judge, or court, based on their belief, which is based on a comprehensive, complete and impartial investigation of all the circumstances of criminal proceedings, shall, in accordance with the law, evaluate each evidence in terms of its suitability, admissibility, reliability, and the totality of evidence collected in terms of sufficiency and interrelation for making the appropriate procedural decision. According to Article 388 of the Criminal Procedural Code of Ukraine jurors take the following oath: "I, (full name), hereby swear to perform my duties honestly and impartially, take into account only the evidence examined in court, be guided by the law, my inner conviction and conscience, as befits a free citizen and a fair person." [3].

Similar rules regarding the decision of the court, based on its inner conviction, the issue of the sufficiency of the evidence to establish the circumstances relevant to the case, exist in the Economic Procedural Code of Ukraine (Articles 79, 86) and in the Administrative Procedure Code of Ukraine (Article 76). However these norms fail to define the concept of 'inner conviction' [4]. 
Such subjective factor as internal conviction of a forensic expert based on objective data obtained in the course of examination of objects of expert evaluation is not excluded but also plays an essential role in forensic analysis [5].

The processes of forming inner conviction of a forensic expert, although they have common aspects with judges and jurors however, significant differences do not allow to treat them as similar [6].

The principle of 'equality of the parties to legal proceedings' provides for equality of their procedural opportunities. Under current conditions, there is no equal opportunity for the prosecution and the defense to resort to special knowledge.

On the other hand, a dubious understanding of competition in criminal proceedings leads to discussions about the feasibility of introducing 'defense examination" and 'prosecution examination', about 'competition of experts' or 'competition of expert opinions'.

The development of the institute of 'requisite knowledge' and the elaboration of the basics of 'forensic examination' entails a legitimate question about their relationship with forensic knowledge. The solution to this problem is related to the limits of criminology and its subject area.

This problem is particularly relevant since the legal acts regulating forensic expertise attempt to classify special knowledge and identify types of forensic examinations.

In addition, these classifications are of a rather dubious nature. Today, the problem of attributing certain examinations to the class of forensic is debatable [7].

In particular, according to Subparagraph 1.2.1 of Paragraph 1.2 Section I of the Instruction concerning appointment and conduct of forensic examinations and expert research, approved by Order of the Ministry of Justice No. 53/5 of October 8, 1998 as amended by the Order of the Ministry of JusticeNo.1350/5 of July 27, 2015 as amended by the Order of the Ministry of Justice No. 83/5 of January 10, 2019 forensic examination shall comprise handwriting examination, linguistic examination of speech, technical examination of documents, examination of weapons and tracks and the circumstances of its use, technical (research signs of damage to the clothing associated with concurrent injuries, which are held in forensics office); graphic arts, portrait; examination of the holograms; video recording; explosive; industrial explosions; materials, substances and products (paints and coatings; polymeric materials; fibrous materials; fuel and lubricants; glass, ceramics; narcotic drugs, psychotropic 
substances, their analogues and precursors; alcohol mixtures; soils; metals and alloys and their products; presence of harmful substances (pesticides) in the environment; substances of chemical production and specialty chemicals; food products; strong and toxic substances); biological.

It should be noted that according to Article 92 of the Constitution of Ukraine, the basis of judicial expertise is determined exclusively by the laws of Ukraine. It can be concluded that departmental instructions and regulations concerning forensic activities should apply exclusively to employees of departments that have adopted such standards and should not apply to civil law relations for the provision of expert services by persons who are not employees of state forensic institutions [8].

The negative factors that limit the rights of the defense party may include the use of the term 'forensic examination' in the legal acts of Ukraine, the essence of which in modern conditions does not fully correspond to its form (name).

The definition of the term 'forensic examination' is very vague and has no clear differential features which would allow it to be allocated to a separate class of forensic examination [9].

Limiting the exclusive right to conduct forensic, forensic medical and forensic psychiatric examinations only to state specialized institutions (Article 7) reflects the 'monopoly' of state specialized institutions in performing certain types of forensic examinations, deprives experts who do not work in these institutions of the opportunity to conduct expert research (deprivation of the profession of an expert).

The restoration of justice should be connected with the possibility of inviting independent experts, conducting alternative examinations, and a wide range of opportunities for applying special knowledge [10].

Among other things, there is an issue of the speed of legal proceedings. The monopoly that is currently observed with examinations delays the very examination process.

For instance, the National Anti-corruption Bureau of Ukraine (hereinafter referred to as $\mathrm{NABU}$ ) notes that sometimes they have to wait quite a long time for the examination required for the further pre-trial investigation of the case (when e.g. there are limited terms of a pre-trial investigation), which directly affects the quality and possibility of bringing the case to court. 
In addition, the existing legislation regarding expertise contradicts the Law of Ukraine 'OnNational anti-corruption Bureau of Ukraine ' No. 1698-18, which indicates that NABU detectives have the right to attract specialists and experts at their discretion (including foreign ones), while the court appoints an expert at its discretion [11].

The change in the procedure of involving an expert in criminal proceedings requires attention. In particular, Article 243 of the Criminal Procedure Code of Ukraine (hereinafter referred to as the CPC of Ukraine) specifies that an expert is involved if there are grounds for conducting an examination on behalf of an investigating judge or court, provided at the request of a party to criminal proceedings.

In this case, the investigator is actually deprived of the right to decide on the involvement of an expert. Article 244 CPC of Ukraine sets the procedure for consideration by an investigating judge of a request for an expert examination.

Certain attempts to establish the "adversarial nature of the parties" are reflected in Article 245 CPC of Ukraine "Obtaining samples for examination".

This provision of the law states that 'if it is necessary to obtain samples for examination, they are taken by the party to the criminal proceedings who requested the examination or upon whose request the examination was appointed by the investigating judge'. At the same time, the procedure for obtaining samples is not actually defined, especially with regard to the actual mechanisms of action on the part of the defense.

To ensure equal opportunities in obtaining samples for comparative research, the legislator allowed the parties to the criminal proceedings to have temporary access to items and documents and, if necessary, to withdraw them (Articles 160-166 of the CPC of Ukraine), as well as to receive samples for examination (Article 245 of the CPC of Ukraine). The question arises: Is it possible to ensure parity of the parties to criminal proceedings in converting these opportunities? [12].

New trends and the latest technologies for conducting examinations encourage scientists to pay attention to digital technologies that can be used not only for good but also with criminal intent. The latest United Nations report, "The Age of Digital Interdependence" - presented in early summer 2019 - addressed the challenges humanity faces in the digital age. In the spring of 2019, the OECD in its report 'Solving Tax Problems of the Digital Economy" thoroughly 
investigated changes in the tax sphere, the principles of income generation through digital tools, including cryptocurrencies [13].

The year 2017 was a turning point in the crypto economy: financial institutions introduced bitcoin futures, major investors began to enter the crypto market, cryptocurrency became a means of accumulation and saving. It becomes obvious that further ignoring of the cryptocurrency is impossible.

Today, the lack of independent legal regulation of creation ('mining') and circulation ('trading') of cryptocurrencies in Ukraine, as well as the lack of appropriate methods for conducting forensic examination generates a legislative vacuum [14].

Currently a new direction of scientific research is being opened, which requires the attention of judicial experts, lawyers, investigative bodies, and courts to this problem.

In particular, the research staff of the Odessa Scientific Research Institute of Forensics (SRIF) is developing a relevant scientific topic.

Conclusion. The situation in forensic science in Ukraine, in particular in matters related to the implementation of forensic activity in court proceedings, requires further elaboration and clarification, taking into account the reform of the judicial system and the development of new trends and new technologies for conducting examinations.

\section{References}

1. G. Filonenko. Democratization of Ukrainian society as a fundamental component of Ukraine's entry into the European space. Veche. 2011. \# 2 (Jan.). P. 12.

2. M.Khaustova. International standards in the context of European integration processes in Ukraine. Journal of National Academy of Legal Sciences of Ukraine \#2 (89) Pp. 44-45.

3. O.Oleinik. Foreign experience of administrative and legal regulation of forensic activities. Customs Business. 2013. No. 4 (88) P. 270.

4. G.K.Avdeeva. Problems of harmonization of Ukrainian legislation in the field of forensic expertise with the legislation of the European Union - access mode http://dspace.nlu.edu.ua/bitstream/123456789/7223/1/Avdeeva_634.pdf

5. I.Pyrig. Classification of forensic examinations and problems of improving legislation, Kharkiv 'Pravo' 2018, p.25, access mode:

https://www.hniise.gov.ua/user_files/File/sbornik/2018/\%d0\%9a\%d0\%be\%d0\%bd\%d1\%84 \%d0\%90\%d0\%ba\%d1\%82\%20\%d0\%bf\%d0\%b8\%d1\%82\%d0\%b0\%d0\%bd\%d0\%bd\%d1\%8 f\%20\%d1\%81\%d1\%83\%d0\%b4\%20\%d0\%b5_2018.pdf 
6. E.Manko. Features of forming the inner conviction of a forensic scientist (versus judge, jury and investigating judge), Kharkiv "Law" 2018, p. 48

7. V.Shepitko. Use of special knowledge in criminal proceedings: current trends and some problems, Collection - Current issues of forensic science, Kharkiv "Pravo" 2018, c.40

8. G.Prokhorov-Lukin, G. Avdeeva. Comment on the draft law of Ukraine "On Forensic Activities", 'Legal Ukraine' magazine, 1/4, p. 45, access mode:

http://dspace.nlu.edu.ua/bitstream/123456789/10348/1/Avdeeva_Prohorov-Lukin_37-62.pdf

9. G.Avdeeva. Forensic examinations: reality or myth? Kryminalist pershodrukovany. 2016. \#13. Pp. 75-78.

12. V.Shepitko. Use of special knowledge in criminal proceedings: current trends and some problems, Collection - Current issues of forensic science, Kharkiv "Pravo" 2018, p. 66

11. Forensic examination: old changes, new consequences - access mode: https://yur-gazeta.com/golovna/sudova-ekspertiza-stari-zmini-novi-naslidki.html

12. V.Shepitko. Use of special knowledge in criminal proceedings: current trends and some problems, Collection - Current issues of forensic science, Kharkiv "Pravo" 2018, p. 65

13. M.Zagryadskaya. Cryptocurrencies in Ukraine, access mode:: https://yurgazeta.com/publications/practice/podatkova-praktika/kriptovalyuti-v-ukrayini.html

14. A.Rebenko. Cryptocurrencies and forensic activities: points of contact, immediate prospects. Collection - Current issues of forensic science, Kharkiv, Pravo Pulishing House 2018, p.40 